\title{
Effect of Different Lung Ventilatory Patterns during and After Cardiopulmonary Bypass on Oxygenation Parameters after Cardiac Surgery in Adults: \\ A Comparative Study
}

\author{
Eslam Reda Abdelhay Hassan, Samia Ibrahim Sharaf, Eman Mohamed Kamal Aboseif, \\ Marwa Mostafa Mohamed \\ Faculty of Medicine - Ain Shams University in Anesthesia Department \\ Corresponding: eslamr1888@gmail.com, Tel: +202 01274554841
}

\begin{abstract}
Background: pulmonary complications after cardiac surgery recorded incidence of $25 \%$ of all cardiac surgeries. Ventilation strategies before and after CPB also cause problems. Alveolar over-distention and reduced lung recruitment are involved in lung injury during general anesthesia in cardiac surgeries. Protective lung ventilation is a common practice during general anesthesia and includes positive end expiratory pressure (PEEP), recruitment maneuvers and the use of $\mathrm{FiO} 2$ levels not greater than $80 \%$. Aim of the Work: the aim of the study was to compare the effect of application of continuous positive airway pressure (C-PAP) ventilation during cardiopulmonary bypass and application of positive end expiratory pressure (PEEP) after cardiopulmonary bypass (CPB) per se or followed by lung recruitment (RM) in the intensive care unit (ICU) on arterial oxygenation after cardiopulmonary bypass. Patients and Methods: after obtaining approval from the medical ethical committee, this study was conducted at Cardiothoracic Academy of Ain Shams University and Ain Shams University specialized hospitals. The study included 66 patients divided into three equal groups. Conclusion: the application of alveolar recruitment strategy showed short term improvement in the arterial oxygenation and ventilation perfusion mismatch in patients undergoing CABG using CPB. Further studies are needed to determine if this beneficial effect of recruitment maneuvers could be further prolonged and produce more lasting clinical effects.
\end{abstract}

Keywords: PEEP: Positive end expiratory pressure; $\mathrm{PaO} 2 / \mathrm{FiO} 2$ : Ratio between partial pressure of arterial oxygen and fraction of inspired oxygen; RMs: Recruitment maneuvers

\section{INTRODUCTION}

Pulmonary complications are common after cardiac surgery. They prolong the duration of hospital stay, contribute to postoperative morbidity, and increase mortality. Pulmonary complications after cardiac surgery recorded incidence of $25 \%$ of all cardiac surgeries ${ }^{(1)}$. These problems range from postoperative pulmonary complications such as atelectasis, pneumonia, pleural effusion and diaphragm dysfunction to severe forms of acute respiratory distress syndrome which cause great effect of morbidity and mortality. Also these problems affect the pulmonary vascular bed and gas exchange mainly postoperative causing deterioration in arterial oxygenation (2). Impairment of gas exchange is reflected by reduction in oxygenation and ratio between partial pressure of arterial oxygen and fraction of inspired oxygen $(\mathrm{PaO} 2 / \mathrm{FiO} 2)$ which called "hypoxic index" after cardiac surgery associated with poor hospital outcome.PaO2/FiO2 (hypoxic index) value of 300 or less indicates reduced efficiency in alveolar-capillary membrane performance ${ }^{(3)}$. CPB is not the only stage in which lung injury might occur. Ventilation strategies before and after CPB also cause problems. Alveolar over-distention and reduced lung recruitment are involved in lung injury during general anesthesia in cardiac surgeries. Protective lung ventilation is a common practice during general anesthesia and includes positive end expiratory pressure (PEEP), recruitment maneuvers and the use of $\mathrm{FiO} 2$ levels not greater than $80 \%{ }^{(4)}$. Recruitment maneuvers (RMs) have been proposed as an adjunct to mechanical ventilation to reverse alveolar derecruitment and improve pulmonary gas exchange. There are different methods to perform RM when using the conventional ICU ventilator. The three RM methods that are mostly used and investigated are sighs, sustained inflation, and extended sigh. There is no standardization of any of the above RM ${ }^{(5)}$.

\section{AIM OF THE WORK}

The aim of the study was to compare the effect of application of continuous positive airway pressure (C-PAP) ventilation during cardiopulmonary bypass and application of positive end expiratory pressure (PEEP) after cardiopulmonary bypass $(\mathrm{CPB})$ per se or followed by lung recruitment $(\mathrm{RM})$ in the intensive care unit (ICU) on arterial oxygenation after cardiopulmonary bypass.

\section{PATIENTS AND METHODS}

Type of Study: A controlled randomized clinical study. Study Setting: After obtaining 
approval from the medical ethical committee, this study was conducted at Cardiothoracic Academy of Ain Shams University and Ain Shams University specialized hospitals. Study Period: 3 months. Study Population: Inclusion Criteria: 1. Patients with no serious co-morbidities, 2. Age group 18 60 years old of both sexes, 3. Patients undergoing elective primary coronary artery bypass graft surgery with CPB. Exclusion Criteria: 1. Patients younger than 18 years old or more than 60 years old, 2. Patients with pre-existing lung disease (COPD, Pulmonary hypertension) with preoperative FEV1 (forced expiratory volume in $1^{\text {st }}$ second) or FRC (functional residual capacity) less than $40 \%$, 3. Patients with morbid obesity, 4. Patients with chronic renal failure, 5. Patients with congestive heart failure, 6. Patients with cardiogenic shock, on inotrope support or hemodynamically unstable, 7. Emergency surgery. Sampling Method: A controlled randomized clinical study is thought to be the most suitable design to achieve the study objectives. Sample Size: The hypoxic index (a ratio) and alveolar to arterial $\mathrm{O} 2$ tension difference $(\mathrm{AaO} 2 \mathrm{D})$ were the primary outcome of this study. Using a relatively large effect size of 0.4 with fixed effects one- way ANOVA with level of significance of 0.05 and power of 0.80 a total sample size of at least 66 patients divided into three equal groups was satisfactory. The sample size was calculated using G*Power program Version 3.1.9.2. Ethical Considerations: After obtaining approval from the medical ethical committee, this study was conducted in Cardiothoracic Academy of Ain Shams University and Ain Shams University specialized hospitals. Study procedures: Preoperative assessment including history taking, clinical examination and laboratory investigations was done the day before the surgery. Laboratory investigations included complete blood count, blood sugar level, coagulation profile (PT, PTT and INR), liver enzymes (AST and ALT), serum urea, serum creatinine. Electro-cardiogram and ECHO were done. Patients were instructed to fast for 8 hours for solid food and for 2 hours for clear liquids. Pre medication was standar-dized to bromazepam $3 \mathrm{mg}$ orally, 1 hour before surgery. Anesthesia was induced with midazolam 0.05 $\mathrm{mg} / \mathrm{kg}$, fentanyl 10 to $\mathrm{mcg} / \mathrm{kg}$, and propofol 0.5 to $1 \mathrm{mg} / \mathrm{kg}$. Pancuronium, $0.1 \mathrm{mg} / \mathrm{kg}$, was administrated to facilitate tracheal intubation.
Anesthesia was maintained with isoflorane on MAC 1.2-1.5\%.After completion of surgery, patients transferred to ICU. All patients under went median sternotomy. Management of CPB included systemic temperature drift to $33^{\circ} \mathrm{C}$ to $34^{\circ} \mathrm{C}$, mean perfusion pressure between 50 and $70 \mathrm{mmHg}$, pump flow rate 2 to $2.4 \mathrm{~L} / \mathrm{min} / \mathrm{m}^{2}$ and hematocrit more than $20 \%$.Before separation from $\mathrm{CPB}$, patients rewarmed to $36^{\circ} \mathrm{C}$ to $37^{\circ} \mathrm{C}$ Intraoperative monitoring including electrocardiogram (ECG), pulse oximetry $\left(\mathrm{SPO}_{2}\right)$, invasive blood pressure (IBP), non-invasive blood pressure (NIBP), capnography $\left(\mathrm{ETCO}_{2}\right)$ and temperature probe. Basal measurements were taken. Study Interventions: Patients were randomly allocated to three groups 22 patients of each:- Group (I): They did not received any pattern of ventilation during CPB (Control group), Group (II): application of CPAP 5-10 cmH2O during CPB with $\mathrm{FiO}_{2} 0.4$ during $\mathrm{CPB}$, This was done by adjust flowmeter on $1 \mathrm{~L} / \mathrm{min}$ as the ventilator on the spontaneous mode and APL valve was adjusted on 5-10 $\mathrm{cmH} 2 \mathrm{O}$. After separation of CPB the PEEP $5 \mathrm{~cm} \mathrm{H}_{2} \mathrm{O}$ applied till the end of the operation, Group (III): application of C-PAP 5-10 $\mathrm{cmH}_{2} \mathrm{O}$ during CPB with $\mathrm{FiO}_{2} 0.4$ and before separation from $\mathrm{CPB}$, manual lung inflation was done at $30 \mathrm{cmH}_{2} \mathrm{O}$ for 5 seconds. Then PEEP $5 \mathrm{cmH}_{2} \mathrm{O}$ started after weaning from CPB till the end of the operation. On arrival to the ICU vital capacity maneuvers (VCM) in the form of lung inflation at pressure $30 \mathrm{cmH}_{2} \mathrm{O}$ for 3 seconds, this maneuver was done as follows, The patient was put on pressure controlled (PC) mode with peak inspiratory pressure (PIP) 30 $\mathrm{cmH}_{2} \mathrm{O}$ for 3 seconds and adjust PEEP $10 \mathrm{cmH}_{2} \mathrm{O}$ during the maneuver for 5 successive breath cycles separated by 5 minutes intervals. Data collection: The primary outcome was measurement of partial pressure of arterial oxygen $\left(\mathrm{PaO}_{2}\right)$ and hypoxic index (the ratio between arterial oxygen tensions to inspired oxygen fraction $\left.\left(\mathrm{PaO}_{2} / \mathrm{FiO}_{2}\right)\right)$. The secondary outcome was the measurement of alveolar to arterial $\mathrm{O}_{2}$ tension difference $\left(\mathrm{AaO}_{2} \mathrm{D}\right)$ at the following pre-determined intervals: 1Baseline before starting $\mathrm{CPB}$ at $\mathrm{FiO}_{2}$ 0.4, 2-End of CPB. 3-15 minutes after weaning of CPB, 4-In ICU at time intervals 1, 2, 4, 6 hours postoperative. Post-operative ventilatory strategy: The surgery was completed and the patients transferred to the intensive care unit, where they were extubated at varying times depending on individual 
circumstances. Transfer from operating theatre to ICU used an ambu-bag connected with $\mathrm{O}_{2}$ cylinder with $\mathrm{FiO}_{2} 100 \%$. Once on the ICU, the patients from all three groups were managed according to the standard postoperative protocols used in this institution. All patients were ventilated with synchronised intermittent mandatory ventilation (SIMV) on $\mathrm{FiO}_{2} 0.4$ at rate of 12 breath/min. Tidal volumes continued at $7-9 \mathrm{ml} / \mathrm{kg}$ depending on $\mathrm{PaCO}_{2}$ measurements. PEEP of $5 \mathrm{cmH}_{2} \mathrm{O}$ was added to all patients. Statistical analysis: Recorded data were analyzed using the statistical package for social sciences, version 20.0 (SPSS Inc., Chicago, Illinois, USA). Quantitative data were expressed as mean \pm standard deviation (SD). Qualitative data were expressed as frequency and percentage. The following tests were done: A one-way analysis of variance (ANOVA) when comparing between more than two means, Chisquare $\left(\mathrm{x}^{2}\right)$ test of significance was used in order to compare proportions between two qualitative parameters. The confidence interval was set to $95 \%$ and the margin of error accepted was set to $5 \%$. So, the $\mathrm{p}$-value was considered significant as the following: Probability (P-value): P-value $<0.05$ was considered significant, p-value $<0.001$ was considered as highly significant, $\mathrm{p}$-value $>0.05$ was considered insignificant.

\section{RESULTS}

Demographic data: Table (1) shows no statistically significant difference between groups according to demographic data (age, sex and body mass index (BMI)).

Table (1): Comparison between groups according to demographic data.

\begin{tabular}{|c|c|c|c|c|c|}
\hline $\begin{array}{c}\text { Demographic } \\
\text { Data }\end{array}$ & $\begin{array}{c}\text { Group I } \\
(\mathbf{N}=\mathbf{2 2})\end{array}$ & $\begin{array}{c}\text { Group II: } \\
(\mathbf{N}=\mathbf{2 2})\end{array}$ & $\begin{array}{c}\text { Group } \\
\text { III: } \\
(\mathrm{N}=22) \\
\end{array}$ & F/x2\# & p-value \\
\hline $\begin{array}{l}\text { Age (years) } \\
\text { Mean } \pm \text { SD }\end{array}$ & $40.95 \pm 7.06$ & $41.74 \pm 7.20$ & $39.94 \pm 6.88$ & 0.848 & 0.414 \\
\hline $\begin{array}{l}\text { Sex } \\
\text { Male } \\
\text { Female } \\
\end{array}$ & $\begin{array}{r}16(72.7 \%) \\
6(27.3 \%) \\
\end{array}$ & $\begin{array}{c}18(81.8 \%) \\
4(18.2 \%) \\
\end{array}$ & $\begin{array}{c}15(68.2 \%) \\
7(31.8 \%) \\
\end{array}$ & $1.109 \#$ & 0.574 \\
\hline $\begin{array}{l}\text { BMI }\left[\mathbf{w t} /(\mathbf{h t})^{2}\right] \\
\text { Mean } \pm \text { SD }\end{array}$ & $29.39 \pm 5.16$ & $28.88 \pm 4.9$ & $30.45 \pm 5.25$ & 0.334 & 0.740 \\
\hline
\end{tabular}

Data presented as Mean \pm SD or number of the patients. $\mathrm{P}$-value $>0.05$ is considered statistically non-significant. F-NOVA test; $\# \mathrm{x}^{2}$ : Chi-square test; P-value >0.05 NS.

Effect on $\mathrm{PaO}_{2}$ : Table (2) shows a comparison between the three groups as regards
$\mathrm{PaO}_{2}$. It reveals a statistically significant difference between the groups according to $\mathrm{PaO}_{2} 1^{\text {st }} \mathrm{hr}$. in ICU, $2^{\text {nd }} \mathrm{hr}$. in ICU and $4^{\text {th }} \mathrm{hr}$. in ICU. At the end of $\boldsymbol{C P B}$ : There was no significant difference $(P$ value equal 0.137) in $\mathrm{PaO}_{2}$ between three groups. 15 mins after $C P B$ : There was no significant difference ( $P$-value equal 0.210$)$ in $\mathrm{PaO}_{2}$ between three groups. In the $\boldsymbol{I}^{\text {st }} \boldsymbol{h r}$ in $\mathbf{I C U}$ : There was a highly significant difference (P-value less than 0.001 ) in Group II in comparison with Group I and significant difference in Group III in comparison with the other two groups ( $P$-value less than 0.001). In the $2^{\text {nd }} \mathbf{h r}$ in ICU: There was a highly significant difference (P-value less than 0.001) in Group II in comparison with Group I and significant difference ( $P$-value less than 0.001) in Group III in comparison with the other two groups. In the $4^{\text {th }} \mathbf{h r}$ in ICU: There was a highly significant difference ( $P$-value equal 0.002) in Group III in comparison with the other two groups. In the $\boldsymbol{6}^{\text {th }} \boldsymbol{h r}$ in ICU: There was no significant difference $(P$ value equal 0.085) in $\mathrm{PaO}_{2}$ between three groups.

Table (2): Comparison between groups according to $\mathrm{PaO}_{2}$ :

\begin{tabular}{|c|c|c|c|c|c|}
\hline $\mathrm{PaO}_{2}:$ & $\begin{array}{c}\text { Group I: } \\
(\mathrm{N}=22)\end{array}$ & $\begin{array}{c}\text { Group II: } \\
(\mathrm{N}=22)\end{array}$ & $\begin{array}{l}\text { Group III: } \\
(\mathbf{N}=22)\end{array}$ & ANOVA & p-value \\
\hline $\begin{array}{l}\text { Base Line } \\
\text { Mean } \pm \text { SD } \\
\end{array}$ & $159.64 \pm 20.00$ & $162.55 \pm 20.18$ & $166.64 \pm 13.97$ & 0.790 & 0.459 \\
\hline $\begin{array}{l}\text { End of CPB } \\
\text { Mean } \pm \text { SD }\end{array}$ & $125.50 \pm 30.92$ & $134.68 \pm 28.64$ & $142.64 \pm 23.02$ & 2.049 & 0.137 \\
\hline $\begin{array}{l}15 \text { mins } \\
\text { after CPB } \\
\text { Mean } \pm \text { SD }\end{array}$ & $124.00 \pm 26.26$ & $135.23 \pm 18.27$ & $131.52 \pm 17.89$ & 1.599 & 0.210 \\
\hline $\begin{array}{l}\text { 1st hr in ICU } \\
\text { Mean } \pm \text { SD }\end{array}$ & $141.55 \pm 23.49$ & $157.18 \pm 21.00^{\circ}$ & $201.00 \pm 18.35^{\mathrm{a}, \mathrm{b}}$ & 45.608 & $<0.001^{* *}$ \\
\hline $\begin{array}{l}\text { 2nd hr in ICU } \\
\text { Mean } \pm S D\end{array}$ & $144.34 \pm 17.17$ & $163.05 \pm 16.08^{\circ}$ & $204.29 \pm 15.54^{\mathrm{a}, \mathrm{b}}$ & 75.849 & $<0.001^{* * *}$ \\
\hline $\begin{array}{l}\text { 4th hr in ICU } \\
\text { Mean } \pm S D\end{array}$ & $151.77 \pm 17.90$ & $163.41 \pm 20.72$ & $175.38 \pm 22.51^{\mathrm{a}}$ & 7.174 & $0.002 *$ \\
\hline $\begin{array}{l}\text { 6th hr in ICU } \\
\text { Mean } \pm S D\end{array}$ & $159.00 \pm 16.51$ & $169.50 \pm 24.86$ & $173.76 \pm 23.92$ & 2.570 & 0.085 \\
\hline
\end{tabular}

Data presented as Mean \pm SD or number of the patients. Pvalue $>0.05$ is considered statistically non-significant; FNOVA test; p-value $>0.05 \mathrm{NS}$; *p-value $<0.05 \mathrm{~S}$; **p-value $<0.001$ HS; a: Significant difference between group I; b: Significant difference between group II 


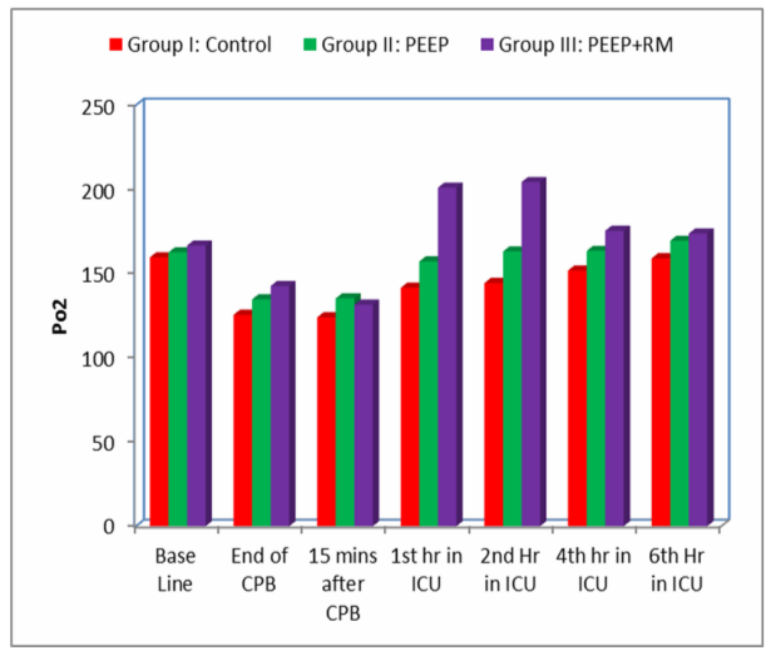

Fig. (1): Bar chart between groups according to $\mathrm{PaO}_{2}$

Effect on hypoxic index $\left(\mathrm{PaO}_{2} / \mathrm{FiO}_{2}\right)$ :

Table (3) shows highly statistically significant difference between groups according to hypoxic index $\left(\mathrm{PaO}_{2} / \mathrm{FiO}_{2}\right)$ in the $1^{\text {st }} \mathrm{hr}$. in ICU and $2^{\text {nd }} \mathrm{hr}$. in ICU but at $4^{\text {th }}$ and $6^{\text {th }}$ hrs. in ICU there was no significant difference in $\mathrm{PaO}_{2} / \mathrm{FiO}_{2}$ between the three groups. At the end of $\boldsymbol{C P B}$ : There was no significant difference (P-value equal 0.133$)$ in $\mathrm{PaO}_{2} / \mathrm{FiO}_{2}$ between three groups. 15 mins after $\boldsymbol{C P B}$ : There was no significant difference ( $P$-value equal 0.209) in $\mathrm{PaO}_{2} / \mathrm{FiO}_{2}$ between three groups. In the $\mathbf{I}^{\text {st }} \mathbf{h r}$ in ICU: There was a highly significant difference and higher $\mathrm{PaO}_{2} / \mathrm{FiO}_{2}$ (P-value less than 0.001 ) in Group II in comparison with Group I and highly significant difference and higher $\mathrm{PaO}_{2} / \mathrm{FiO}_{2}$ (P-value less than 0.001) in Group III in comparison with the other two groups. In the $2^{\text {nd }}$ $\boldsymbol{h r}$ in ICU: There was a highly significant difference and higher $\mathrm{PaO}_{2} / \mathrm{FiO}_{2}(P$-value less than 0.001 ) in Group II in comparison with Group I and significant difference and higher $\mathrm{PaO}_{2} / \mathrm{FiO}_{2}(P$ value less than 0.001) in Group III in comparison with the other two groups. In the $4^{\text {th }}$ hr in ICU: There was no significant difference $(P$-value equal 0.216) in $\mathrm{PaO}_{2} / \mathrm{FiO}_{2}$ between three groups. In the $\boldsymbol{G}^{\text {th }} \boldsymbol{h r}$ in ICU: There was no significant difference ( $P$-value equal 0.087$)$ in $\mathrm{PaO}_{2} / \mathrm{FiO}_{2}$ between three groups.
Table (3): Comparison between groups according to hypoxic index $\left(\mathrm{PaO}_{2} / \mathrm{FiO}_{2}\right)$ :

\begin{tabular}{||l|c|c|c|c|c||}
\hline \hline PaO $_{2} / \mathbf{F i O}_{2}:$ & $\begin{array}{c}\text { Group I: } \\
(\mathbf{N}=\mathbf{2 2})\end{array}$ & $\begin{array}{c}\text { Group II: } \\
(\mathbf{N}=\mathbf{2 2})\end{array}$ & $\begin{array}{c}\text { Group III: } \\
(\mathbf{N}=\mathbf{2 2})\end{array}$ & ANOVA & p-value \\
\hline $\begin{array}{l}\text { Base Line } \\
\text { Mean } \pm \text { SD }\end{array}$ & $394.09 \pm 52.44$ & $411.59 \pm 46.76$ & $415.18 \pm 33.72$ & 1.357 & 0.265 \\
\hline $\begin{array}{l}\text { End of CPB } \\
\text { Mean } \pm \text { SD }\end{array}$ & $313.75 \pm 77.30$ & $339.55 \pm 71.45$ & $356.61 \pm 57.56$ & 2.082 & 0.133 \\
\hline $\begin{array}{l}\text { 15 mins after CPB } \\
\text { Mean } \pm \text { SD }\end{array}$ & $307.36 \pm 67.63$ & $332.93 \pm 40.67$ & $332.48 \pm 49.99$ & 1.604 & 0.209 \\
\hline $\begin{array}{l}\text { 1st hr in ICU } \\
\text { Mean } \pm \text { SD }\end{array}$ & $352.77 \pm 59.00$ & $400.14 \pm 48.57^{\mathrm{a}}$ & $475.19 \pm 104.52^{\mathrm{a}, \mathrm{b}}$ & 14.988 & $<0.001^{* * * *}$ \\
$\begin{array}{l}\text { 2nd hr in ICU } \\
\text { Mean } \pm \text { SD }\end{array}$ & $365.39 \pm 52.89$ & $408.30 \pm 39.73^{\mathrm{a}}$ & $495.05 \pm 62.40^{\mathrm{a}, \mathrm{b}}$ & 34.093 & $<0.001^{* * * *||}$ \\
\hline $\begin{array}{l}\text { 4th hr in ICU } \\
\text { Mean } \pm \text { SD }\end{array}$ & $377.18 \pm 51.15$ & $414.50 \pm 147.52$ & $433.56 \pm 97.42$ & 1.570 & 0.216 \\
\hline $\begin{array}{l}\text { 6th hr in ICU } \\
\text { Mean } \pm \text { SD }\end{array}$ & $397.39 \pm 41.33$ & $422.99 \pm 78.73$ & $439.07 \pm 57.72$ & 2.541 & 0.087 \\
\hline
\end{tabular}

F-NOVA test; p-value $>0.05 \mathrm{NS}$; $* *$ p-value $<0.001 \mathrm{HS}$; a: Significant difference between group I; b: Significant difference between group II

Data are presented as Mean \pm SD or number of the patients. P-value $>0.05$ is considered statistically non-significant

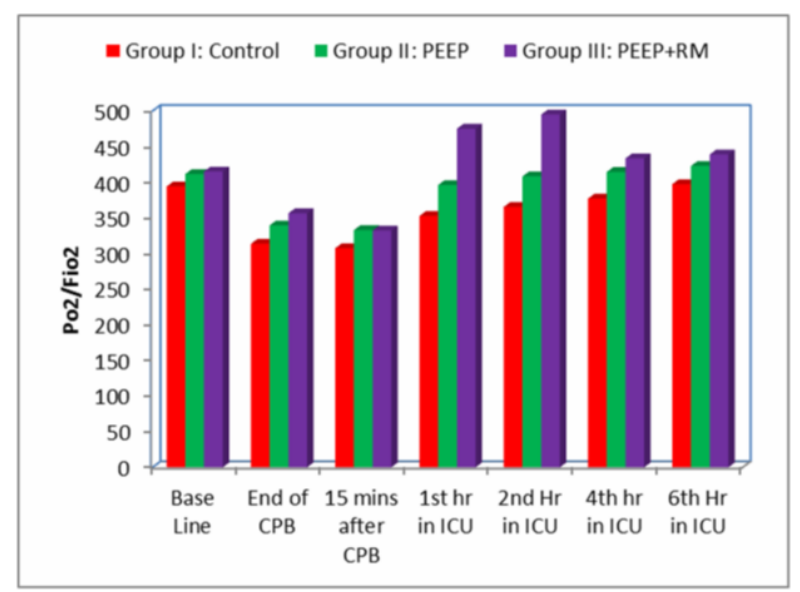

Fig. (2): Bar chart between groups according to $\mathrm{PaO}_{2} / \mathrm{FiO}_{2}$.

Effect on $\mathrm{AaO}_{2} \mathrm{D}_{\text {: }}$ Table (4) shows statistically significant difference between groups according to $\mathrm{AaO}_{2} \mathrm{D}$ in the $1^{\text {st }} \mathrm{hr}$ in ICU, $2^{\text {nd }} \mathrm{hr}$ in ICU. At the end of $C P B$ : There was no significant difference ( $P$-value equal 0.086) in $\mathrm{AaO}_{2} \mathrm{D}$ between three groups. In 15 mins after CPB: There no significant difference (P-value equal 0.059$)$ in $\mathrm{AaO}_{2} \mathrm{D}$ between the three groups. In the $\boldsymbol{I}^{\text {st }} \boldsymbol{h r}$ in $\boldsymbol{I C U}$ : There was a highly significant difference and lower $\mathrm{AaO}_{2} \mathrm{D}(P$-value less than 0.001) in Group II in comparison with Group I and significant difference and lower $\mathrm{AaO}_{2} \mathrm{D}$ (P-value less than 0.001 ) in Group III in comparison with the other two groups. In the $2^{\text {nd }} \boldsymbol{h r}$ in $\mathbf{I C U}$ : There was a highly significant difference and lower $\mathrm{AaO}_{2} \mathrm{D}(P$ - 
value less than 0.001) in Group II in comparison with Group I and a highly significant difference and lower $\mathrm{AaO}_{2} \mathrm{D}$ (P-value less than 0.001) in Group III in comparison with the other two groups. In the $\boldsymbol{6}^{\text {th }} \mathbf{h r}$ in $\mathbf{I C U}$ : There was no significant difference (P-value equal 0.472) in $\mathrm{AaO}_{2} \mathrm{D}$ between the three groups.

Table (4): Comparison between the three groups according to $\mathrm{AaO}_{2} \mathrm{D}$.

\begin{tabular}{|c|c|c|c|c|c|}
\hline Aao2D: & $\begin{array}{l}\text { Group I: } \\
(\mathrm{N}=22)\end{array}$ & $\begin{array}{c}\text { Group II: } \\
(\mathrm{N}=22)\end{array}$ & $\begin{array}{l}\text { Group III: } \\
(\mathrm{N}=22)\end{array}$ & ANOVA & p-value \\
\hline $\begin{array}{l}\text { Base Line } \\
\text { Mean } \pm \text { SD }\end{array}$ & $72.98 \pm 21.90$ & $66.12 \pm 21.97$ & $67.79 \pm 14.30$ & 0.716 & 0.493 \\
\hline $\begin{array}{r}\text { End of CPB } \\
\text { Mean } \pm \text { SD }\end{array}$ & $104.64 \pm 25.35$ & $112.82 \pm 54.27$ & $87.55 \pm 23.48$ & 2.553 & 0.086 \\
\hline 15 min after CPB & $108.23+23.76$ & $99.27 \pm 19.08$ & $97.19 \pm 17.87$ & 2.847 & 0.059 \\
\hline $\begin{array}{c}\text { 1st hr in ICU } \\
\text { Mean } \pm \text { SD } \\
\end{array}$ & $94.18 \pm 23.03$ & $70.48 \pm 18.78^{\mathrm{a}}$ & $31.19 \pm 19.10^{\mathrm{a} b}$ & 52.021 & $<0.001 * *$ \\
\hline $\begin{array}{l}\text { 2nd hr in ICU } \\
\text { Mean } \pm \text { SD }\end{array}$ & $88.66 \pm 26.65$ & $68.86 \pm 14.47^{\mathrm{a}}$ & $27.10 \pm 12.79^{\mathrm{a} b}$ & 58.027 & $<0.001$ *** \\
\hline $\begin{array}{l}\text { 4th hr in ICU } \\
\text { Mean } \pm \text { SD }\end{array}$ & $88.77 \pm 10.57$ & $92.00 \pm 0.00$ & $92.00 \pm 0.00$ & 2.003 & 0.144 \\
\hline $\begin{array}{c}\text { 6th hr in ICU } \\
\text { Mean } \pm \text { SD }\end{array}$ & $78.36 \pm 19.16$ & $72.55 \pm 23.46$ & $68.62 \pm 20.51$ & 5.127 & 0.472 \\
\hline
\end{tabular}

Data presented as Mean \pm SD or number of the patients. $\mathrm{P}$-value $>0.05$ is considered statistically non-significant; F-NOVA test; p-value >0.05 NS; *p-value <0.05 S; **pvalue <0.001 HS; a: Significant difference between group I; b: Significant difference between group II.

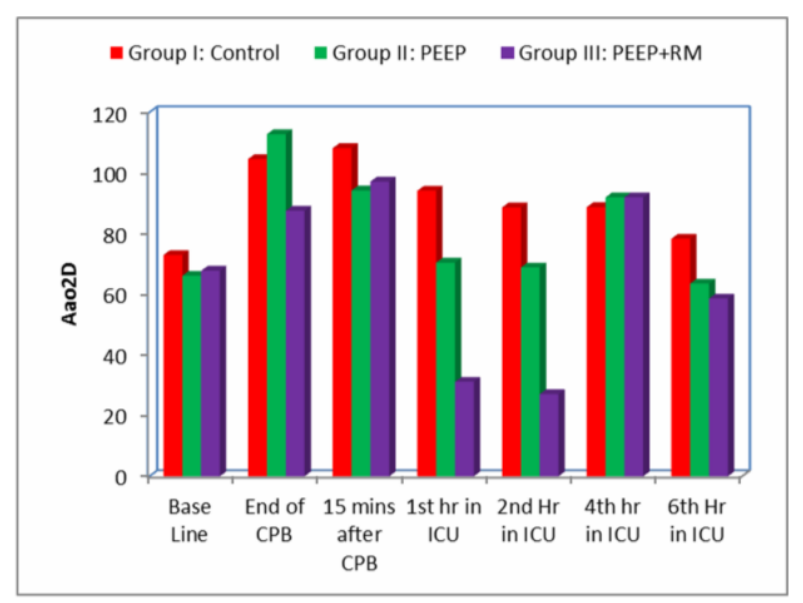

Fig. (3): Bar chart between groups according to $\mathrm{AaO}_{2} \mathrm{D}$.

\section{DISCUSSION}

Patients undergoing CABG using CPB can suffer from deterioration of pulmonary functions in the postoperative period. During CPB the lungs are unventilated or deflated ${ }^{(6)}$. Cessation of the pulmonary circulation and ventilation during $\mathrm{CPB}$ may lead to atelectasis and may markedly contribute to inflammatory reactions in the lung which lead to postoperative pulmonary complications. The potential mechanisms of $\mathrm{CPB}$ related lung dysfunction involve pulmonary atelectasis, intrapulmonary shunt and change in systemic immune and inflammatory status (6). Although the causes of postoperative hypoxemia after cardiac surgery with CPB are multifactorial, formation of lung atelectasis appear to be the primary factor responsible for increased hypoxemia and intrapulmonary shunt after cardiac surgery. As many as $64 \%$ of patients have radiologically confirmed atelectasis after $\mathrm{CPB}{ }^{(7)}$. The current study indicated that the application of C-PAP during CPB per se or followed by successive lung RMs would improve oxygenation in the post bypass period in ICU during and after cardiac surgery. The oxygenation parameters examined in this study was $\mathrm{PaO}_{2}$, hypoxic index $\left(\mathrm{PaO}_{2} / \mathrm{FiO}_{2}\right)$ and $\mathrm{AaO}_{2} \mathrm{D}$. Ratio of $\mathrm{PaO}_{2} / \mathrm{FiO}_{2}$ was an acceptable parameter allowing comparison of oxygenation between the patients who used wide range of $\mathrm{FiO}_{2}$. $\mathrm{FiO}_{2} 0.4$ was used throughout the study to avoid the harmful effect of hyperoxia. Ventilation with $\mathrm{FiO}_{2}$ 100\% need higher PEEP levels to keep lung opened. If lungs are ventilated with $100 \%$ oxygen atelectasis occur after 5 minutes after recruitment (8). Effect of C-PAP on oxygenation parameters: The results of this study showed that application of C-PAP 5-10 $\mathrm{cmH}_{2} \mathrm{O}$ during CPB had no beneficial effect on oxygenation parameters in the immediate post CPB period. The results of this current study are in agreement with those of Altmay et al. ${ }^{(9)}$ who studied the effect of C-PAP 5-10 $\mathrm{cmH}_{2} \mathrm{O}$ during $\mathrm{CPB}$ on $\mathrm{AaO}_{2} \mathrm{D}$ and shunt fraction and showed no significant improvement in these parameters. In addition, Figueiredo et al. ${ }^{(10)}$ showed similar results when they studied the effect of C-PAP 5-10 $\mathrm{cmH}_{2} \mathrm{O}$ on $\mathrm{PaO}_{2} / \mathrm{FiO}_{2}$ ratio and $\mathrm{AaO}_{2} \mathrm{D}$. The results of Zabeeda et al. ${ }^{(11)}$ study revealed that the effect of C-PAP $5 \mathrm{cmH}_{2} \mathrm{O}$ with $\mathrm{FiO}_{2} 100 \%$ induced an improvement on $\mathrm{PaO}_{2} / \mathrm{FiO}_{2}$ ratio and $\mathrm{AaO}_{2} \mathrm{D}$ while using C-PAP $5 \mathrm{cmH}_{2} \mathrm{O}$ with $\mathrm{FiO}_{2} 0.21$ exerted nonsignificant changes in the same parameters. Loeckinger et al. ${ }^{(12)}$ study results were inconsistent with the current results as they studied the effect of C-PAP $10 \mathrm{cmH}_{2} \mathrm{O}$ during $\mathrm{CPB}$ on $\mathrm{PaO}_{2} / \mathrm{FiO}_{2}$ ratio, $\mathrm{AaO}_{2} \mathrm{D}$ and shunt fraction and showed positive effect on these parameters. Effect of lung recruitment strategies: The results of the present study pointed out that application of C-PAP during $\mathrm{CPB}$ followed by PEEP alone starting from end of 
CPB and extended in ICU (as a measure of ventilator strategy according to the standard postoperative protocols) exerted an improvement on oxygenation parameters in comparison with the control group who were extended to the $2^{\text {nd }}$ hour in the ICU. In contrast to the present study Claxton et al. ${ }^{(13)}$ and Scherer et al. ${ }^{(14)}$ showed that PEEP $5 \mathrm{cmH}_{2} \mathrm{O}$ application post CPB caused no effect on oxygenation parameters in the first three hours in the ICU. The difference between the current results and others may be attributed to the effect of using C-PAP 5-10 $\mathrm{cmH}_{2} \mathrm{O}$ during CPB before application of PEEP $5 \mathrm{cmH}_{2} \mathrm{O}$ later on. The conclusions of our study gave indication that repetitive application of vital capacity maneuvers (VCM) showed highly a significant improvement in gas exchange (hypoxic index), oxygenation and VQ mismatch which extend to the $2^{\text {nd }}$ hour in the ICU. Also, the investigations showed a trend of improvement of $\mathrm{PaO}_{2}$ towards the $4^{\text {th }}$ hour in the ICU. These beneficial effects suggest reversal of any lung atelectasis. The current findings are in agreement with those of Minkovich et al. ${ }^{(7)}$ who showed that application of two only VCM during and after CPB had an improvement effect on $\mathrm{PaO}_{2} / \mathrm{FiO}_{2}$ ratio extended three hours after CPB. Tschernko et al. (15) examined the application of repeated VCM three times before termination of CPB. However, the results of this study couldn't abolish the effect of shunting and hypoxemia after CPB. Claxton et $\boldsymbol{a l}{ }^{(13)}$ investigated the effect of alveolar recruitment strategy on patients undergoing CPB. They attained a significant improvement of oxygenation parameters up to one hour post CPB.

\section{CONCLUSION}

The application of alveolar recruitment strategy showed short term improvement in the arterial oxygenation and ventilation perfusion mismatch in patients undergoing $\mathrm{CABG}$ using CPB. Further studies are needed to determine if this beneficial effect of recruitment maneuvers could be further prolonged and produce more lasting clinical effects.

\section{CONFLICTS OF INTEREST}

There are no conflicts of interest.

\section{REFERENCES}

1- Apostolakis EE, Koletsis EN, Baikoussis NG, Siminelakis SN, and Papadopoulos GS (2010): Strategies to prevent intraoperative lung injury during cardiopulmonary bypass. Journal of cardiothoracic surgery, 5(1):1

2- Ibanez J, Riera M, Amezaga R, Herrero J, Colomar A, Campillo-Artero, C, de Ibarra J.S and Bonnin O (2016): Longterm mortality after pneumonia in cardiac surgery patients: a propensity-matched analysis. Journal of intensive care medicine, 31(1): 34-4.

3- Esteve F, Lopez-Delgado JC, Javierre C, Skaltsa K, Carrio ML, RodríguezCastro D, Torrado H, Farrero E, DiazPrieto A, Ventura JL and Mañez $R$ (2014): Evaluation of the $\mathrm{PaO} 2 / \mathrm{FiO} 2$ ratio after cardiac surgery as a predictor of outcome during hospital stay. BMC anesthesiology, (1):83.

4- Ferrando C, Soro M, and Belda FJ (2015): Protection strategies during cardiopulmonary bypass: Ventilation, anesthetics and oxygen. Curr Opin Anaesthesiol 28:73-80.

5- Guerin C, Debord S, Leray V, Delannoy B, Bayle F, Bourdin G, and Richard JC (2011): Efficacy and safety of recruitment maneuvers in acute respiratory distress syndrome. Annals of Intensive care, 1(1):9.

6- Bignami E, Guarnieri M, Saglietti F, Belletti A, Trumello C, Giambuzzi I, Monaco F, and Alfieri $O$ (2016). Mechanical ventilation during cardiopulmonary bypass. Journal of cardiothoracic and vascular anesthesia, 30(6):1668-75.

7- Minkovich L,Djaiani G, Katznelson R, Day F, Fedorko L, Tan J, Carroll J, Cheng D, and Karski J (2007): Effects of alveolar recruitment on arterial oxygenation in patients after cardiac surgery: a prospective, randomized, controlled clinical trial. Journal of cardiothoracic and vascular anesthesia, 21(3):375-8. 
8- Rothen HU, Sporre B, Engberg G, Wegenius G, Hogman $M$, and Hedenstierna G (1995): Influence of gas composition on recurrence of atelectasis after a reexpansion maneuver during general anesthesia. Anesthesiology: The Journal of the American Society of Anesthesiologists,82(4):832-42.

9- Altmay E, Karaca P, Yurtseven NÖzkul V, Aksoy T, Özler A, and Canik S (2006): Continuous positive airway pressure does not improve lung function after cardiac surgery. Canadian Journal of Anesthesia,53(9):919-25.

10- Figueiredo LC, Araújo S, Abdala RC, Abdala A, and Guedes CA (2008): $\begin{array}{lllll}\mathrm{CPAP} & \text { at } 10 & \mathrm{~cm} & \mathrm{H} 2 \mathrm{O} & \text { during }\end{array}$ cardiopulmonary bypass does not improve postoperative gas exchange. Brazilian Journal of Cardiovascular Surgery, 23(2): 209-15.

11- Zabeeda D, Gefen R, Medalion B, Khazin V, Shachner A, and Ezri T (2003): The effect of high-frequency ventilation of the lungs on postbypass oxygenation: A comparison with other ventilation methods applied during cardiopulmonary bypass. Journal of cardiothoracic and vascular anesthesia, 17(1):40-4.
12-. Loeckinger A, Kleinsasser A, Lindner KH, Margreiter J, Keller $\mathrm{C}$, and Hoermann C (2000): Continuous positive airway pressure at $10 \mathrm{~cm} \mathrm{H} 2 \mathrm{O}$ during cardiopulmonary bypass improves postoperative gas exchange. Anesthesia \& Analgesia,91(3):522-7.

13- Claxton BA, Morgan $P$, McKeague $H$, Mulpur A, and Berridge J (2003): Alveolar recruitment strategy improves arterial oxygenation after cardiopulmonary bypass. Anaesthesia, 58(2):111-6

14-Scherer $M$, Dettmer S, Meininger $D$, Deschka H, Geyer G, Regulla C, and Moritz A (2009): Alveolar recruitment strategy during cardio-pulmonary bypass does not improve postoperative gas exchange and lung function. Cardiovascular Engineering,9(1): 1.

15- Tschernko EM, Bambazek A, Wisser W, Partik B, Jantsch U, Kubin K, Ehrlich $M$, Klimscha $W$, Grimm $M$, and Keznickl FP (2002): Intrapulmonary shunt after cardiopulmonary bypass: the use of vital capacity maneuvers versus off-pump coronary artery bypass grafting. The Journal of thoracic and cardiovascular surgery,124(4): 732-8. 